\title{
Biochemical and molecular identification of lactic acid bacteria isolated from camel milk in Tunisia
}

\author{
Imen Fguiri' ${ }^{12 *}$, Moufida Atigui ${ }^{1}$, Manel Ziadi², Samira Arroum', Touhami Khorchani ${ }^{1}$ \\ ${ }^{1}$ Laboratory of Livestock and Wild life Institute of Arid lands (IRA Medenine), 4119, Médenine, Tunisia, University of Gabes; \\ ${ }^{2}$ Laboratory of Microbial Technology and Ecology (LETMi), National Institute of Applied Sciences and Technology (INSAT), BP 876, 1080 \\ Tunis, Tunisia
}

\section{A B S TR A C T}

\begin{abstract}
This study aimed to compare biochemical vs. molecular methods for identification of Lactic Acid Bacteria (LAB) isolated from camel milk. Ten strains among 62 LAB isolates were chosen for identification using API50CHL and 16S rDNA sequencing. Only Gram-positive and catalase-negative isolates were considered. Citrate utilization, in the presence of carbohydrates, was studied. These strains were tested from the growth in $\mathrm{NaCl}(4,6.5 \%)$, growth at different temperature $\left(10-45^{\circ} \mathrm{C}\right)$ and growth at different $\mathrm{pH}$ values (4.2, 9.6). Results indicated that ten (10) strains were identified as: Lactococcus lactis, Lactobacillus pentosus, Lactobacillus plantarum, Lactobacillus brevis and Pediococcus pentosaceus by using biochemical method. However by molecular methods, all strains were identified as Enterococcus faecium. It was, thereby, concluded that each technique had its limitations but the molecular analysis is the most reliable.
\end{abstract}

Keywords: Biochemical identification; Molecular identification; Lactic acid bacteria

\section{INTRODUCTION}

In arid regions, camel milk is considered as one of the most important source of dairy products for human diet with potential therapeutic effects. Recent studies showed that camel milk is a natural source for probiotics (Al-Otaibi et al., 2013). The dominant and beneficial microflora in camel milk represented by LAB is a potential source of biological materials to be used in dairy technology (Khedid et al., 2009). LAB strains are characterized by their ability to transform lactose, to improve the digestibility (Weinberg et al., 2007) and to preserve fermented dairy products (Abdelbasset and Djamila, 2008). They were also employed for improvement of the taste, texture and viscosity in the manufacture of dairy products (Soukoulis et al., 2007). Health promoting properties of probiotic LAB (Temmerman et al., 2002; Kalliomäki et al., 2001) render this group of microorganisms' essential importance in dairy industry which gives added values for dairy product.

Studies are continually being conducted to identify and characterize new LAB with this usage potential (Perin et al., 2014; Fguiri et al., 2015). Because many LAB have similar nutritional and growth requirements, biochemical-based methodologies for identification might not be conclusive in many cases. The conventional microbiological methods for bacterial identification are based on morphological and physiological characteristics such as Gram staining, cell shape, spore formation, enzyme production and the fermentation of different carbohydrates (Moraes et al., 2013). Phenotypic identification and biochemical tests have been considered for a long time the conventional procedure for routine identification of bacteria. Several methods have been developed in the last few years and many commercial multi-test kits such as the analytical profile index (API) test kits are widely used.

Recently, new molecular tools have been applied for the routine identification of microbes, and had led to an increase in the number of identified bacteria (Gevers and Coenye, 2007; Liu and Stahl, 2007; Bittar and Rolain, 2010). Most of the advance molecular methods are based on 16S ribosomal DNA sequences, complete or partial genomes (Ben Amour et al., 2007). Although molecular approaches remain the standard techniques for bacterial identification that have been proved to be very sensitive, they have some

\footnotetext{
*Corresponding author:

Imen Fguiri, Laboratory of Livestock and Wild life Institute of Arid lands (IRA Medenine), 4119, Médenine, Tunisia, Tel.: +21675321260;

Fax: +21675633006, E-mail: imen.fguiri@yahoo.com
} 
limitations. The limits of these advanced techniques has been questioned due to the extent of their database, the need for complex procedures, trained personnel, specialized and expensive, equipment.

Considering the available techniques for identifying LAB, the objective of this study was to compare molecular and phenotypic methods for identifying LAB isolates: API50CHL and $16 \mathrm{~S}$ rDNA sequencing.

\section{MATERIAL AND METHODS}

\section{Sampling}

Milk samples were collected from camels (Camelus dromadarius) belonging to the herd of the Arid lands Institute (IRA Medenine). The samples were immediately cooled $\left(4^{\circ} \mathrm{C}\right)$ and brought to the laboratory in an isotherm containers and were analyzed immediately thereafter.

\section{Bacterial isolation and characterization}

LAB were isolated on Man-Rogosa-Sharp (MRS) (Pronadisa, Madrid, Spain) agar and incubated at $30^{\circ} \mathrm{C}$ for 24 to $48 \mathrm{~h}$ in order to apply the conventional tests for identification (Nguyen et al., 2007; Kopermsub and Yunchalard, 2010). All isolates were initially examined for Gram staining and catalase production. Only Grampositive and catalase-negative isolates were considered. Citrate utilization, in the presence of carbohydrates, was studied on Simmons citrate medium (Fluka Biochemica). The presence of a blue coloration (even only locally on the surface) indicated a positive reaction. These strains were tested from the growth in $\mathrm{NaCl}(4,6.5 \%)$, growth at different temperature $\left(10-45^{\circ} \mathrm{C}\right)$ and growth at different $\mathrm{pH}$ values $(4.2,9.6)$.

\section{Biochemical methods}

Fermentation of carbohydrates was determined using API 50 CHL, a standardized system, consisting of 50 biochemical tests for the study of carbohydrate metabolism by microorganisms. API $50 \mathrm{CH}$ was used in conjunction with API 50 CHL medium for the identification of Lactobacillus and related genera strips according to the manufacturer's instructions (Biomerieux, Marcy l'Etoile, France) (Ghanbari et al., 2009). Briefly, $10 \mathrm{ml}$ of pure water was dispensed with the strip placed in the incubation box, after the bacterial cultures had been introduced into the API 50 CHL system in API 50 CHL medium $(5 \mathrm{ml})$. The set-up system was then incubated at appropriate temperature of $30^{\circ} \mathrm{C}$ for 24 and $48 \mathrm{~h}$, after the wells were filled with the bacterial suspensions by the line mark with the addition of paraffin oil. Identification tables were prepared as (+/-) according to colour change in evaluation of results of API strips reaction. Numerical profiles of strains were identified adding positive values in indicative table. The API LAB
PLUS database (Bio Merieux, France) was used for the interpretation of the results.

\section{Molecular method}

The genomic DNA of ten strains was extracted using the DNA extraction and purification kit according to the manufacturer instructions (Fermentas, UK). The PCR reaction mixture contained $0.5 \mu \mathrm{L}$ of template DNA, $2.5 \mu \mathrm{L}$ of reverse primer $(10 \mathrm{mM}), 2.5 \mu \mathrm{L}$ of forward primer $(10 \mathrm{mM}), 2 \mu \mathrm{L}$ of $\operatorname{dNTP}(25 \mathrm{mM}), 4 \mu \mathrm{L}$ of $\mathrm{MgCl} 2(25 \mathrm{mM}), 5 \mu \mathrm{L}$ of PCR buffer (10X) and $1 \mu \mathrm{L}$ Taq polymerase, in a $50 \mu \mathrm{L}$ final volume. The primers sequences used were S1 (5'AGAGT'T'TGATC (A,C) TGGCTCAG 3') et S2 (5' GG (A,C) TACCT'TGTTACGA (T,C) T'TC 3') for an $400 \mathrm{bp}$ expected product size. The cycling program was $94^{\circ} \mathrm{C}$ for $3 \mathrm{~min}, 29 \mathrm{cycles}$ at $94^{\circ} \mathrm{C}$ for $40 \mathrm{sec}, 55^{\circ} \mathrm{C}$ for $50 \mathrm{sec}$ and $72^{\circ} \mathrm{C}$ for $2 \mathrm{~min}$. Sequencing of PCR product was made by the sequencing facility offered by Eurofins (Germany). The obtained nucleotide sequences, displayed by BioEdit software, were analyzed using the blast tool of the NCBI site in order to research identity percentages with the sequences present in databases (http://blast.ncbi.nlm. nih.gov/Blast.cgi).

\section{RESULTS AND DISCUSSION}

\section{Isolation of lactic acid bacteria}

A total of 62 strains were isolated from MRS agar. All of them grew at $37^{\circ} \mathrm{C}$ under anaerobic conditions, were Gram positive, non-motile and catalase negative as preliminary characteristics. Only 29 of them were citrate positive. In microscopy, the cells had different shapes coccobacilli, cocci and bacilli, forming small chains of varying length, pairs or in clusters and were immobile. Only 10 strains were subjected to identification with biochemical and molecular methods. The ten strains encoded SCC1-2, SCC1-6, SCC1-7, SCC1-8, SCC1-13, SCC1-15, SCC1-24, SCC1-33, SLch6 and SLch14 are characterized by their ability to grow at different temperatures $\left(10,39\right.$ and $\left.45^{\circ} \mathrm{C}\right)$ at different salt concentrations $(4,6.5)$ while growth of these strains at $8 \%$ of salts concentration were not observed. All strains grew only at $\mathrm{pH}=9.6$ (Table 1). The strains of Gram-positive cocci form grouped in pairs or small chains represent the Lactococcus or Enterococcus. Furthermore, the distinction between the two kinds of Enterococcus and Lactococcus were affected upon growth tests at varying temperatures and at different concentrations of salts $(4 \%, 8 \%$ and $6.5 \% \mathrm{NaCl})$. Indeed, enterococci grew at $45{ }^{\circ} \mathrm{C}$ and tolerate salinity $6.5 \%$ and a $\mathrm{pH}$ of 9.6, while lactococci did not grew under these conditions (Axelsson et al., 1998).

\section{Biochemical identification of lactic strains}

Ten strains chosen according to the difference in cell morphology were identified using API galleries. Regarding 
Fguiri, et al.: Biochemical and molecular identification of LAB

Table 1: Fermentation profiles of lactic acid bacteria isolated from camel milk

\begin{tabular}{|c|c|c|c|c|c|c|c|c|c|c|}
\hline Strains & $\mathrm{SLC}_{\mathrm{ch} 6}$ & $\operatorname{SCC}_{1,7}$ & $\mathrm{SLC}_{\mathrm{ch} 14}$ & $\mathrm{SCC}_{1,13}$ & $\mathrm{SCC}_{1,33}$ & $\mathrm{SCC}_{1,15}$ & $\operatorname{SCC}_{1,24}$ & $\mathrm{SCC}_{1,6}$ & $\operatorname{SCC}_{1,8}$ & $\mathrm{SCC}_{1,2}$ \\
\hline Glycerol & + & - & w & w & + & w & - & w & w & + \\
\hline L-Sorbose & - & - & - & - & w & - & - & - & - & - \\
\hline D-Sorbitol & - & - & - & - & - & + & - & + & - & - \\
\hline Amygdaline & - & + & + & w & w & + & - & + & - & - \\
\hline Esculin & + & + & w & w & + & + & w & w & + & w \\
\hline D-Melezotse & - & - & - & - & - & - & - & + & - & w \\
\hline Amidon & - & w & + & w & + & - & w & - & w & $w$ \\
\hline Identification & $\begin{array}{l}\text { L. lactis ssp } \\
\text { lactis1 }\end{array}$ & $\begin{array}{l}\text { Lb } \\
\text { plantarum }\end{array}$ & $\begin{array}{l}\text { L. lactis ssp } \\
\text { lactis1 }\end{array}$ & $\begin{array}{l}\text { L lactis ssp } \\
\text { lactis1 }\end{array}$ & $\begin{array}{l}\text { L.lactis ssp } \\
\text { lactis1 }\end{array}$ & $\begin{array}{l}\text { Lb } \\
\text { pentosus }\end{array}$ & $\begin{array}{l}\text { L. lactis } \\
\text { ssp lactis1 }\end{array}$ & $\begin{array}{l}\text { Pediococcus } \\
\text { pentosaceus }\end{array}$ & $\begin{array}{l}\text { Lb } \\
\text { plantarum }\end{array}$ & Lb brevis \\
\hline
\end{tabular}

+: Positive, w: Weakly positive, -: Negative after $48 \mathrm{~h}$ of incubation at $37^{\circ} \mathrm{C}$. All strains fermented : L-Arabinose, D-Ribose, D-Xylose, D-Galactose, D-Glucose, D-Fructose, D-Mannose, N-AcetylGlucosamine, Arbutine, Salicine, D-Celibiose, D-Maltose, D-Lactose, D-Melibiose, D-Saccharose, D-Trehalose, D-Tagatose, Non fermented: Xylitol, Glycogene, Inuline, Methyl-aD-Mannopyranoside, Methyl-aD-Glucopyranoside, Inositol, Dulcitol, Methyl-ßD-Xylopyranside, D-Adonitol, L-Xylose, Erythirol, D-Arabinose

the carbohydrates fermentations the strains were divided in two groups (Table 2). The first ones dominated by regular rods (SCC18, SCC17, SCC115, SCC12) which fermented mostly Amygdaline, Sorbitol, Esculine and Glycerol, were tentatively identified as Lb. plantarum, $L b$. pentosus and Lb. brevis. The second group was coccoid in shape (SLCch14, SLCch6, SCC113, SCC133, and SCC12). They fermented mostly, glycerol, esculine, amygdaline and amidon. They were tentatively identified as L. Lactis 1 and Pediococcus pentosaceus. Earlier studies reported the presence of the Lactobacillus plantarum and lactobacillus brevis in Sudanese fermented camel milk (Ashmaig et al., 2009). Sun et al. (2010) isolated the Lactobacillus plantarum and Lactococcus lactis from traditional fermented milk in Mongolia.

\section{Molecular phylogeny of the selected isolates}

The selected strains (10 strains) were identified by partial sequencing of the gene coding for the $16 \mathrm{~S}$ rRNA. The phylogenetic relationship of the experimental sequence and its close relatives were analyzed through the facilities of the Ribosomal Database Project (http://rdp.cme. msu.edu/). All the isolates were identified as Enterecoccus faecium (Table 2). E. faecium was previously isolated from Egyptian camel milk (Hamed and Elaatar, 2013) and from Azerbaijani Motal cheese (Ahmadova et al., 2013; Akhmetsadykova et al., 2014). Enterococci, components of the human gastro-intestinal microbiota (Huycke et al., 1998), are very widespread in various raw food systems especially of animal origin (Haji-Sfaxi et al., 2011). They can be frequently associated to fermented foods (Franz et al., 2003) including cheeses and fermented milk (FoulquiéMoreno et al., 2006).

\section{Comparison of API with sequencing of 16S rDNA gene}

The different methods of evaluation provided different patterns of genera and species identification for the LAB isolates (Table 2). Regarding the results by sequencing of $16 \mathrm{~S}$ rDNA gene, the only specie identified was Enterococcus faecium, whereas API50CHL mostly identified Lactobacillus spp., Lactococcus, Pediococcus. These results were
Table 2: Comparison between bichemical and molecular techniques of identification of LAB

\begin{tabular}{|c|c|c|}
\hline Strains & API $50 \mathrm{CH}$ & Sequencing of $16 \mathrm{~S}$ rDNA gene \\
\hline SCC1-2 & Lactobacillus brevis & Enterococcus faecium JN5609 \\
\hline $\operatorname{scC} 1-6$ & Pediococcus pentosaceus & Enterococcus faecium KF1493 \\
\hline $\operatorname{SCC} 1-7$ & Lactobacillus plantarum & Enterococcus faecium JX8476 \\
\hline SCC1-8 & Lactobacillus plantarum & Enterococcus faecium JQ7265 \\
\hline SCC1-13 & $\begin{array}{l}\text { Lactococcus lactis ssp } \\
\text { lactis1 }\end{array}$ & Enterococcus faecium EU8781 \\
\hline SCC1-15 & Lactobacillus pentosus & Enterococcus faecium KC4227 \\
\hline SCC1-24 & $\begin{array}{l}\text { Lactococcus lactis ssp } \\
\text { lactis1 }\end{array}$ & Enterococcus faecium JN5609 \\
\hline SCC1-33 & $\begin{array}{l}\text { Lactococcus lactis ssp } \\
\text { lactis1 }\end{array}$ & Enterococcus faecium JN5608 \\
\hline SLch6 & $\begin{array}{l}\text { Lactococcus lactis ssp } \\
\text { lactis1 }\end{array}$ & Enterococcus faecium $\mathrm{HM} 1624$ \\
\hline SLch14 & $\begin{array}{l}\text { Lactococcus lactis ssp } \\
\text { lactis1 }\end{array}$ & Enterococcus faecium AY5877 \\
\hline
\end{tabular}

similar to finding of Moreas et al. (2013). Differences between sequencing and phenotypic tests have already been observed previously, not just for LAB but also for many other bacteria (Aymerich et al., 2003; Velasco et al., 2004; Gomes et al., 2008). Despite being the most reliable test, sequencing has some disadvantages. Because it is so conserved, in somecases the $16 \mathrm{~S} \mathrm{rDNA}$ gene is not sufficient for differentiating between species of LAB, especially Enterococcus spp. (Aymerich et al., 2003; Mohania et al., 2008). Considering the difficulties in differentiating between some LAB species with $16 \mathrm{~S}$ rDNA sequencing and phenotypic tests, the application of specific molecular techniques such as species-specific PCR is necessary. For example, the identification of Enterococcus spp. is based on the detection of the d-alanine-ligase enzyme, antibiotic resistance and specific regions (Dutka-Malen et al., 1995). Species specific PCR is also useful for identifying microorganisms at subspecies level, which cannot be easily achieved with other common techniques (Beimfohr et al., 1997). Another disadvantage is the time required to obtain the sequencing results, which is considerably higher than the time needed to obtain phenotypic test results. 


\section{CONCLUSION}

In conclusion, the choice of identification method must be carefully analyzed. Some factors must be considered, the number of isolates to be identified, and staff qualifications. A phenotypic test could be used as a trial test, but the molecular methods are more accurate and should be used as confirmatory tests for hard to-identify isolates. Considering that most of the LAB isolation and identification studies aim to detect potential biopreservative isolates from food, the molecular approach is probably the most sensitive.

\section{ACKNOWLEDGMENTS}

Authors are grateful to Ms Mona Assadi for her assistance during this work.

\section{Conflict of interest}

Authors declare no conflict of interest.

\section{Author contributions}

I. F. and M. A. wrote the article and corrected it. M. Z. and T. K. designed the study. I. F. and S. A. conducted the experimental work.

\section{REFERENCES}

Abdelbasset, M. and K. Djamila. 2008. Antimicrobial activity of autochthonous lactic acid bacteria isolated from Algerian traditional fermented milk "Raïb". Afr. J. Biotechnol. 7: 29082914.

Agrawal, M., S. Arora, J. Li, R. Rahmani, L. Sun, A. F. Steinlauf and J. I. Mechanick. 2011. Bone, inflammation, and inflammatory bowel disease. Curr. Osteoporos. Rep. 9: 251-257.

Agrawal, R. 2005. Probiotic: An emerging food supplement with health benefits. Food Biotechnol. 19: 227-246.

Ahmadova, A., S. D. Todorov, Y. Choiset, H. Rabesona, T. M. Zadi, A. Kuliyev, B. D. G. Franco, J. M. Chobert and T. Haertlé. 2013. Evaluation of antimicrobial activity, probiotic properties and safety of wild strain Enterococcus faecium AQ71 isolated from azerbaijani motal cheese. Food Control. 30: 631-641.

Akhmetsadykova, S., A, Baubekova, G. Konyspayeva, N. Akhmetsadykova and G. Loiseau. 2014. Microflora identification of fresh and fermented camel milk from Kazakhstan. Emirates J. Food Agric. 26: 327-332.

Al-Otaibi, M. M., N. S. Al-Zoreky and H. A. El-Dermerdash. 2013. Camel's milk as a natural source for probiotics. Res. J. Microbiol. 8: $70-80$.

Ashmaig, A., A. Hasan and E. El Gaali. 2009. Identification of lactic acid bacteria isolated from traditional Sudanese fermented camel's milk (Gariss). Afr. J. Microbiol. Res. 3: 451-457.

Axelsson, L., T. Katla, M. Bjornslett, V. G. H. Eijsink and A. Holck. 1998. A system for heterologous expression of bacteriocins in Lactobacillus sake. FEMS Microbiol. Letter. 168: 137-143.

Aymerich, T., B. Martín, M. Garriga and M. Hugas. 2003. Microbial quality and direct PCR identification of lactic acid bacteria and nonpathogenic staphylococci from artisanal low-acid sausages Appl. Environ. Microbiol. 69: 4583-4594.

Beimfohr, C., W. Ludwig and K. H. Schleifer. 1997. Rapid genotypic differentiation of Lactococcus lactis subspecies and biovar. Syst. Appl. Microbiol. 20: 216-221.

Ben Amour, K., E. E. Vaughan and W. M. Vos. 2007. Advanced molecular tools for the identification of lactic acid Bacteria. J. Nutr. 137: 741S-747S.

Bittar, F. and J. M. Rolain. 2010. Detection and accurate identification of new or emerging bacteria in cystic fibrosis patients. Clin. Microbiol. Infect. 16: 809-820.

Dutka-Malen, S., S. Evers and P. Courvalin. 1995. Detection of glycopeptides resistance genotypes and identification to the species level of clinically relevant enterococci by PCR. J. Clin. Microbiol. 33:24-27.

Elagamy, E. I., R. Ruppanner, A. Ismail, C. P. Champagne and R. Assaf. 1992 Antibacterial and antiviral activity of camel milk protective proteins. J. Dairy Res. 59: 169-75.

Fguiri I., M. Ziadi, M. Atigui, N. Ayeb, S. Arroum, M. Assadi and T. Khorchani. 2015. Isolation and characterization of lactic acid bacteria strains from raw camel milk for potential use in the production of fermented Tunisian dairy products. Int. J. Dairy Tech. doi: 10.1111/1471-0307.12226. (In Press).

Foulquié-Moreno, M. R., P. Sarantinopoulos, E. Tsakalidou, L. De Vuyst. 2006. The role and application of enterococci in food and health. Int. J. Food Microbiol. 106: 1-24.

Franz, C. M., M. E. Stiles, K. H. Schleifer and W. H. Holzapfel. 2003. Enterococci in foods a conundrum for food safety. Int. J. Food Microbiol. 88: 105-122.

Gevers, D. and T. Coenye. 2007. Phylogenetics and genomic analysis. In: Manual of Environmental Microbiology. Hurst, C.J., R. L. Crawford, J. L. Garland, D. A. Lipson, A. L. Mills and L. D. Stetzenbach, editors. ASM Press, Washington, D. C., pp. 139156.

Ghanbari, M., M. Rezaei, M. Jami and R. M. Nazari. 2009. Isolation and characterization of Lactobacillus species from intestinal contents of beluga (Huso huso) and Persian sturgeon (Acipenser persicus). Iran. J. Vet. Res. 10: 152-157.

Gomes, B. C., C. T. Esteves, I. C. V. Palazzo, A. L. C. Darini, G. E. Felis, L. A. Sechi, B. D. G. M. Franco and E. C. P. de Martinis. 2008. Prevalence and characterization of Enterococcus spp. Isolated from Brazilian foods. Food Microbiol. 25: 668-675.

Hadji-Sfaxi, I., S. El-Gaish, A. Ahmadova, B. Batdorj, G. Le BlayLaliberté, G. Barbier, T. Haertlé and J. M. Chobert. 2011. Antimcrobial activity and safety of use of Enterococcus faecium PC4.1 isolated from Mongol yogurt. Food Control. 22: 20202027.

Hamed, E. and A. Elattar. 2013. Identification and some probiotic potential of lactic acid Bacteria isolated from Egyptian camels milk. Life Sci. J. 10: 1952-1961.

Huycke, M. M., D. F. Sahm and M. S. Gilmore. 1998. Multiple-drug resistant enterococci: The nature of the problem and an agenda for the future. Emerg. Infect. Dis. 4: 239-249.

Kalliomäki, M., S. Salminen and H. Arvilommi. 2001. Probiotics in primary prevention of atopic disease: A randomised placebocontrolled trial. The Lancet. 357: 1076-1079.

Khedid, K., M. Faid, A. Mokhtari, Z. A. Soulaymani and A. Zinedine. 2009. Characterization of lactic acid bacteria isolated from the one humped camel milk produced in Morocco. Microbiol. Res. 64: 81-91.

Kopermsub, P. and S. Yunchalard. 2010. Identification of lactic acid bacteria associated with the production of plaa-som, a traditional 
fermented fish product of Thailand. Int. J. Food Microbiol. 138: $200-204$

Liu, W. and D. A. Stahl. 2007. Molecular approaches for the measurement of density, diversity, and phylogeny. In: R. L. J. L. D. A. A. L. L. D. editors. Manual of Environmental Microbiology. ASM Press, Washington, D. C., pp. 139-156.

Mohania, D., R. Nagpal, M. Kumar, A. Bhardwaj, M. Yadav, S. Jain, F. Marotta, V. Singh, O. Parkash and H. Yadav. 2008. Molecular approaches for identification and characterization of lactic acid bacteria. J. Dig. Dis. 9: 190-198.

Moraes, P. M., L. M. Perin, A. S. Júnior and L. A. Nero. 2013. Comparison of phenotypic and molecular tests to identify lactic acid bacteria. Braz. J. Microbiol. 44: 109-112.

Nguyen, T. D. T., J. H. Kang and M. S. Lee. 2007. Characterization of Lactobacillus plantarum $\mathrm{PH} 04$, a potential probiotic bacterium with cholesterol-lowering effects. Int. J. Food Microbiol. 113: 358-361.

Perin, L. M. and L. A. Nero. 2014. Antagonistic lactic acid bacteria isolated from goat milk and identification of a novel nisin variant Lactococcus lactis. BMC Microbiol. 14: 36.

Saltanat, H., H. Li, Y. Xu, J. Wang, F. Liu and X. H. Geng. 2009. The influences of camel milk on the immune response of chronic hepatitis B patients. Xi Bao Yu Fen Zi Mian Yi Xue Za Zhi. 25: 431-433.

Soukoulis, C., P. Panagiotidis and R. Koureli. 2007. Industrial yogurt manufacture: Monitoring of fermentation process and improvement of final product quality. J. Dairy Sci. 90: 2641-2654.

Sun, Z. H., W. J. Liu, J. C. Zhang, J. Yu, W. Gao, M. Jiri, B. Menghe, T. S. Sun and H. P. Zhang. 2010. Identification and characterization of the dominant lactic acid Bacteria isolated from traditional fermented milk in Mongolia. Folia Microbiol. 55: 270-276.

Temmerman, R., B. Pot and G. Huys. 2002. Identification and antibiotic susceptibility of bacterial isolates from probiotic products. Int. J. Food Microbiol. 81: 1-10.

Velasco, D., S. Perez, F. Penã, M. A. Dominguez, M. Cartelle, F. Molina, R. Moure, R. Villanueva and G. Bou. 2004. Lack of correlation between phenotypic techniques and PCR-based genotypic methods for identification of Enterococcus spp. Diagn. Microbiol. Infect. Dis. 49: 151-156.

Weinberg, Z., O. Shatz and Y. Chen. 2007. Effect of lactic acid bacteria inoculants on in vitro digestibility of wheat and corn silages. J. Dairy Sci. 90: 4754-4762. 